\title{
TEORETICAL APPROACH CONCERNING THE DEVELOPMENT OF SUSTAINABLE TOURISM AS TOURIST DESTINATION IN KOSOVO
}

\author{
Bekë KUQI* \\ University "Haxhi Zeka" Peja, Business Faculty, St. "Eliot Engel", \\ 30000 Peja, Kosovo, e-mail: beke.kuqi@unhz.eu
}

Citation: Kuqi, B. (2018). TEORETICAL APPROACH CONCERNING THE DEVELOPMENT OF SUSTAINABLE TOURISM AS TOURIST DESTINATION IN KOSOVO. GeoJournal of Tourism and Geosites, 22(2), 489-496. https://doi.org/10.30892/gtg.22218-305

\begin{abstract}
Abtract: Tourism is an economic activity or a set of co-ordinated activities aimed at meeting the needs of individuals related to leisure and movement of people. Tourism has a great potential and plays an important role in meeting the main objectives related to, employment, sustainable economic and social development. Kosovo's tourism economy is dominated by small and medium-sized economic operators, while large economic operators are still in the process of privatization, and therefore it is required to find a favorable sectorial strategy that in the long term will ensure the sustainability of tour operators, offering a diversified tourist product. The findings of this study give special importance to institutional challenges that require identification of responsibilities and coordination of all actors involved in the tourism planning and development process. The surveyed tourism region offers critical reviews on how to assist tourism planners to improve their methods in community-based tourism planning and development, while pointing to directions for future research into tourist regions. The main focus of the paper is the treatment of tourism development theories in Kosovo and the analysis of the practices of other countries to increase the economic development of the country, the right information about the natural resources of the country in order to be a local tourist attraction not only for tourists but also for foreigners. The metedology used in the work has focused on the theoretical and practical aspect, the comparative aspect, and the logical link between the paragraphs. This paper is intended to provide theoretical and practical knowledge of the tourism in Kosovo of natural resources, regulations and benefits that tourists will achieve during their visit to Kosovo. Knowledge offered for theoretical and practical lexus and all other scientific research through reading this work to gain knowledge and to pass those knowledge to use and practice during their professional exercise.
\end{abstract}

Key words: Tourism, strategy, planning, development, resources, etc

\section{INTRODUCTION}

This paper will enable the recognition of the appropriate strategy, based on the analysis made, the development and implementation of the strategies in practice,

\footnotetext{
* Corresponding author
} 
compared to the strategies encountered in scientific literature, tourism as well as good practices implemented by the developers of tourism in countries with consolidated tourism economies. Through this study will be determined the role and importance of sustainable tourism model for tour operators operating with their tourism activities in a competitive environment that can face the opportunities and loopholes that the surrounding environment brings to you.As the paper will define the best possible way to achieve goals through defined objectives and detailed plans, tour operators will find the way through which they can achieve their business goals, not just the introduction and survival in the market, but the maximum profit and growth of enterprises by increasing the market share, meeting the tourist requirements.

\section{Sustainable Tourism}

At a time when the global economy is in a very varied period of time, the efforts for orientation for sustainable economic development have the advantage of providing new solutions for decision-makers who, encourage debate on sustainable economic development. Economic development provides citizens with a development that can meet the needs of the present, but without hurting the capacity to meet the needs for future generations. This new economic thought, its priority is the citizen who places it in the spotlight for political decision-makers. The concept of sustainable development, which is being built today, is very different from previous economic concepts, especially the economy after the economic crisis of the `3os of the last century, because this concept of sustainable development offers new ideas about how to organize the foundations of a stable economy in these critical moments, and when there are clear signs that the global economy can not move toward industrial growth without ending in the disaster anyway. Sustainable development is defined in different ways by different thinkers. The most recognized and accepted definition: "Development that meets the needs of the present without harming the ability of future generations to meet their needs.The economy is, first and foremost, a subsistem of human society, which is itself, in the second place, a subsistem of the whole life of life on Earth. And, there is no subsistem that can be expanded beyond the overall system capacity, part of which is" (Porritt, 2004).

The principles of the new economies include:

Systematic empowerment of people as a basis for people focused on development. This is based on a realistic picture of human nature, recognizing that people are selfish, cooperative, and competitive. Systematic conservation of resources and environment, as a basis for sustainable development for the environment. Evolution, from a "wealth of nations" model of economic life, into a model world and from the international economy into an ecologically sustainable economic system. Restoration of political and ethical factors for a central place in economic life and respect for quality values, not just quantitative ones, respect for female values, not just male ones. These principles are important for every segment of economic life, thought in every level, ranging from personal and family. New economic policies for sustainable development will focus more directly on people, as active citizens and recycle a portion of public income directly to citizens (Bajrami, 2015: 7).

\section{Goals of Sustainability of Development}

WCED (1987: 6) says sustainability has been achieved through sustainable development strategies, is a concept that got real sense through the Brundtland Report. The concept of sustainable development arises from the belief that economic growth, though important to the community, has limitations. But, according to Brundtland's report, the concept of sustainable development does not imply absolute limitations, but constraints imposed by the current state of technology and social organization for environmental resources and the ability of the biosphere to absorb the effects of human 
activities. According to the WTO, in this way, resources remain capable of supporting future generations as well as current generations (WTO, 1993). Sustainable tourism includes social responsi-bility, a strong description of nature and the integration of local people in any operation or tourism development (Bakiu, 2011: 12).

As demonstrated by UNEP and UNWTO (2011)., investments in green and sustainable tourism are a means of creating jobs and reducing poverty, while simultaneously improving environmental performance (Chapter on Tourism in the Green Economy Report, jointly prepared by UNEP and UNWTO (1987) Sustainability of tourism development is based on natural goods, legal-economic infrastructure constructed by the state and implemented in the proper manner by competent institutions, it is also important to build a development strategy to absorb as much investment as possible to invest in the development of tourism. Through this development of natural goods by joining with a modern infrastructure, tourism is also of interest to foreign tourists, as well as the development of tourism is more sustainable.

\section{Development Resource Development Centers}

The resources available to a country for tourism development, or what are called different tourism potential of a country, are the determining factors for the "production" of the tourism products and services community or those that can name some places or areas as tourist destinations.

These factors are:

$\checkmark$ Natural resources;

$\checkmark$ Historical, artistic and cultural heritage,

$\checkmark$ Human resources,

$\checkmark$ Resources in Capital and Infrastructure.

Depending on the use and good management of a country's resources, the positioning of the global tourism market can be explained in line with the best models of their development and management (Bakiu, 2011: 19).

\section{RESEARCH METHOD}

The methodology of this paper is based on the study of literature and empirical study. Literature studies utilize secondary data such as books, scientific journals, official publications, websites. While the empirical study consists of treating Kosovo as a tourist destination, the model of its development should aim at sustainability. In the case study analysis, a combination of qualitative and quantitative methods of study was done. Primary data are based on qualitative research and quantitative research. So in this study the use of different techniques consists in coordinating findings from the literature review. Research methodology has been developed based on the three main actors of a tourist destination. Timur \& Getz (2008) oncluded that there is no universal definition for the actors. However, the stakeholder groups defined by Bramwell and Lane (2012) support "rules, inter-sectoral interactions between the parties based on at least some rules and agreed rates in order to address a common issue or achieve a political or specific purpose". According to Maxwell (2005), he use of existing literature helps to better understand what the researcher is considering and makes him more aware of particular issues and new phenomena.

\section{KOSOVO AND THE FUNDAMENTAL RESOURCES OF THE SUSTAINABLE TOURISM STRATEGY DEVELOPMENT}

Kosovo has favorable geographic positions and possesses important underground, surplus, human resources as well as appropriate climate, flora and fauna. The geographical position represents its natural pertinence. Kosovo is a Balkan, 
Mediterranean and European country. It is a transitional region, through which geostrategic routes from Western and Northern Europe go to the Middle East and beyond, as well as from the Mediterranean to the eastern European countries. Compared to the relatively small area of Kosovo natural resources as "latent national capital" that are not sufficiently traced represent a delightful potential that with a multidisciplinary approach in the framework of regional and broader integrations can create new development perspectives. Kosovo's tourist values account for a relatively large number of motifs both from heterogeneity and from background. Because of the attractive motives, Kosovo faces many countries in the former Yugoslavia. The concentration of numerous tourist and natural and anthropogenic motives has stemmed from natural specifications, and the historical social conditions in the past but also in the future. The rich tourist motives and their appropriate (linear) and grouping (adequately) position show that the territory of Kosovo represents specific tourist motives in the former Yugoslavia, consisting of Kosovo's and Dukagjini's lowlands and the motives of Sharri, (Albanian Alps) and the Kopaunik Mountains. In such a large number of anthropogenic motifs, cultural and historical motives, old settlements and ethnographic-ethnological motives are concentrated with their specifics. Kosovo as well as developing countries in the first place must maintain the natural goods at the same time to develop based on the practices of the developed countries. As a political one should have the tourism not only to be sustainable but also competitive in the countries in regioon and european.

\section{Kosovo's climate}

Kosovo's climate is related to its geographical position (Figure 1). Its extension to the medium geographic width, the climate of Kosovo depends on the amount of heat coming from the Sun, the proximity of the Adriatic Sea, the Vardar valley, the opening towards the north, the altitude over $400 \mathrm{~m}$, the extension of the high mountains to the west, south the north and the lower and middle mountains in the east and southeast.

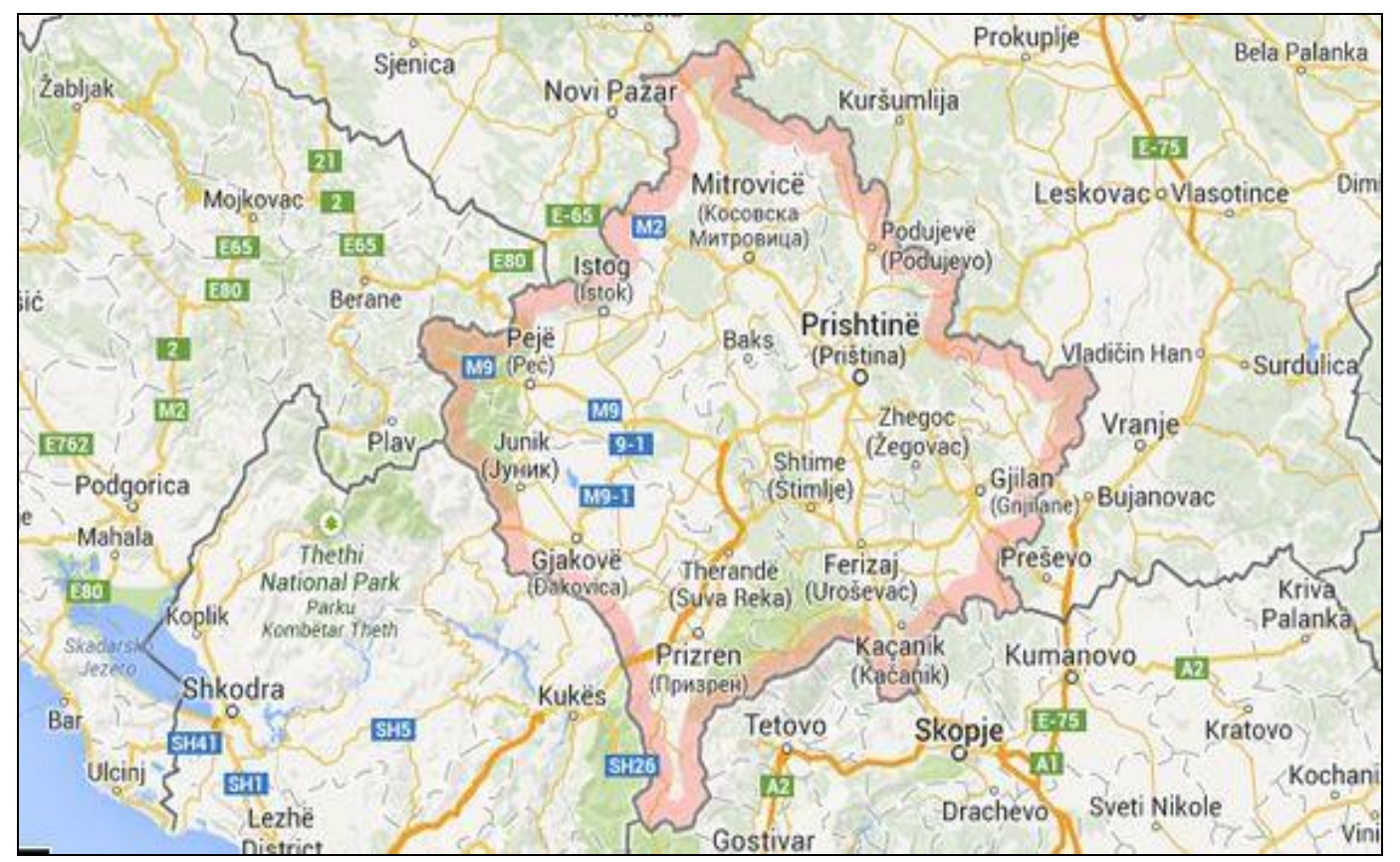

Figure 1. Sketch of Kosovo (Source: /pristina-flights/sherrelirell.1) 
Such geographic circumstances influence Kosovo's climate to have distinct features in the western and eastern parts of the area, So the climatic features vary from west to east and north to south. The sunset affects the geographical latitude (sunset angle), the relief (height, exposure), the sunset, the winds. In our geographical latitudes (42-43 degrees), the annual sunset would have to last 4450-4460 hours per year or 12.2 hours per day 9 on average (www.ammk-rks, 2018). Indeed the sunrise in Kosovo lasts 2079 hours or 5.7 hours a day, which is $47 \%$ of the solar potential. The smallest sunset is in mountainous areas and close to them and during the winter months. The sunset in December is averaged 54 hours in total or 1.7 hours a day, whereas during the summer months (over 250 hours per month or 8.3 hours per day (www.ammk-rks, 2018) Covering the cloudy sky in Kosovo ranges between $52-58 \%$ and is somewhat smaller in the plain of Kosovo than in the Dukagjini Plain. Cloud coverings vary by month. The highest is in the winter months, towards the end of autumn and the beginning of spring, when there is more rainfall and fog. More dead days lie near the high mountains (Albanian Alps and Sharr), and less on the Kosovo plain, Anamorava and Drenica. Air temperature - The temperature fluctuates during the day and the months. The temperature is lower in January $\left(-0.9^{\circ} \mathrm{C}\right)$, higher in July and August $\left(20.9^{\circ} \mathrm{C}\right)$. The average temperature in Kosovo in the winter season is about $1^{\circ} \mathrm{C}$, in autum spring about $10.8^{\circ} \mathrm{C}$, in the summer $20.8^{\circ} \mathrm{C}$. Kosovo's annual temperature ranges from $9^{\circ} \mathrm{C}$ to Podujevo up to $12^{\circ} \mathrm{C}$ in Prizren, Dukagjin $11^{\circ} \mathrm{C}$, Kosovo plains $10^{\circ} \mathrm{C}$, submarine areas $7^{\circ} \mathrm{C}$, mountain ranges between $\mathrm{O}^{\circ} \mathrm{C}$ (Luboten) and $2^{\circ} \mathrm{C}$ in Kopaonik. So the worst is Dukagjini that the plain of Kosovo, Drenica and Llapi.

The positive temperature values in Kosovo move between +37 and $39^{\circ} \mathrm{C}$, while the extreme negative values are between $-22.5^{\circ} \mathrm{C}$ and $-32.5^{\circ} \mathrm{C}$ (Rruga Luan Haradinaj, 2018) The worst negative values in Kosovo are rarer, otherwise they bring great damage to agriculture, especially the vines and trees. Days with frost average last about 90 days and are more frequent in the plains of Kosovo than in Dukagjini. The period under zero temperature lasts from the first decade of October until the first decade of April. In Kosovo, the temperature is between $25^{\circ} \mathrm{C}$ and $30^{\circ} \mathrm{C}$, while the number of days with tropical temperatures (over $30^{\circ} \mathrm{C}$ ) is between $25-30$ days, more in Dukagjini than in Kosovo. Tropical temperatures most often appear in July and August, but they occur in June and May (www. ammk-rks). What is more important is that in Kosovo the climate is very favorable to tourists because the seasons are adapted in climatic time according to official dates and in rare cases the climate happens to be different, such as the winter season every year it is snowy season, and summer is summer season, and not once in the summer season do not snow.

\section{The importance of sector in the development of sustainable}

The private and public sector have a special role to play in the development of tourist destinations especially in countries where tourism is at an early stage of development. The public sector should be in the service of many issues such as regulation of development policies, definition of rules and regulations on tourism, development of key infrastructures, promotion of tourism and development of marketing in order to promote tourism in tourist areas. On the other hand, the public sector function within the tourism industry is to increase tourism pleasure and to increase the tourist offer by increasing economic and business success, protecting existing assets and maintaining the integration of communities in tourist activities (Gunn, 1994). The public sector should also have broad involvement in the planning and implementation of established laws that have to do with tourist destinations and management of infrastructure construction and other prerequisites for the development of sustainable tourism. This public sector should 
also provide conditions and space through instruments such as infrastructure and superstructure, security, and various social values as well as access to these elements. Also, the public sector should provide activities that have to do with culture and history and offer products that are designed and created for public use. As examples of these products that have created the public sector and are in the forefront of this sector these spaces are: national parks, various state parks with recreational areas and monuments and sports grounds (Gunn, 1994). From this, it is noted that the public sector precedes the new tourist developments, while the private sector exploits this space and offer by investing in the tourism destination of the tourist destination (Gashi, 1986). The public sector for the development of tourism sustainability has an obligation to draft modern laws to implement them well in practice to build a juncture of development strategies and to support them finally to create a spin-off coordination in the private sector in order for the development program to implement more easier and better as well as professionally based on special specializations of the private sector.

Tourism represents a socio-economic phenomenon spread among many factors and social entities as in many parts of the world a part of the social and economic development policy where the state takes an active part in promoting this as a special economic and social activity. In the spatial relationships where people live, work and travel, as well as those that result from traveling, the socioeconomic effects are to be sought, the values that come from the participants in the tourist traffic and from all the spatial processes that cause the touristic movements. From the beginning of the development of tourism so far the tourist circulations in the world are massively massive, so tourism as a social and economic phenomenon has undergone structural and essential changes. Touristic flows are an inseparable form of tourism phenomenon which is subject to scientific and operational tourism research. The world's tourist phenomenon is characterized by high degree of massiveness, so the economic effects caused by it are found in various scientific or practical research environments. Recognition of the tourist turnover is a prerequisite for the formation of the right notion of the tourist phenomenon which results in social and economic effects.

Table 1. Number of tourists and nights in Kosovo for the period 2010-2015

Source: Kosovo Agency of Statistics, 2016 (http://ask.rks-gov.net/)

\begin{tabular}{|c|c|c|c|c|c|c|}
\hline \multirow{2}{*}{ Year } & \multicolumn{3}{|c|}{ Number of tourists } & \multicolumn{3}{c|}{ Stay nights } \\
\cline { 2 - 7 } & Domestic & Foreign & Total & Domestic & Foreign & Total \\
\hline $\mathbf{2 0 1 0}$ & 44662 & 34382 & 79044 & 45123 & 76394 & 121517 \\
\hline $\mathbf{2 0 1 1}$ & 42044 & 30349 & 72393 & 44757 & 65584 & 110341 \\
\hline $\mathbf{2 0 1 2}$ & 49973 & 48790 & 98763 & 52008 & 90968 & 142976 \\
\hline $\mathbf{2 0 1 3}$ & 45380 & 50074 & 95454 & 54867 & 83883 & 138750 \\
\hline $\mathbf{2 0 1 4}$ & 46477 & 61313 & 107790 & 55274 & 102066 & 157340 \\
\hline $\mathbf{2 0 1 5}$ & 60200 & 79238 & 139438 & 81372 & 120669 & 202041 \\
\hline
\end{tabular}

The table show that the number of tourists who visited Kosovo steadily increased from 2010 to 2015 and during this period almost doubled the number of tourists. On the other hand, the number of local tourists is almost identical with 2010 in 2014, and by 2015 this number is significantly increased. The situation is different with foreign tourists due to the increase in their number is going higher rates, so from about 35 thousand foreign guests in 2010, this number reaches to nearly 80 thousand. As for staying nights, and here the situation is similar because in 2010 the interior guests realized over 45 
thousand nights, and already in 2015 this number is over 81 thousand stays realized overnight. Foreign tourists generated over 76,000 nights in 2010, while 120,000 nights were spent in 2015. Thus, according to the above data, as the most successful year for tourism in Kosovo in terms of number of tourists realized during the night stays in 2015.

The most visited region of Kosovo by the number of tourists realized overnight stands is the capital Pristina, where in 2015 there were over 89 thousand tourists realized 130 thousand guesthouses, which represents about $64 \%$ of the total number of tourists and over $64 \%$ of tourists total realized at night stays at the state level. The second region according to the number of tourists in Peja with about 22 thousand tourists who created almost 34 thousand nights. Therefore, both regions account for $89 \%$ of total tourists and $81 \%$ of the population in Kosovo. The negative trend in the research period shows only Ferizaj, because the number of tourists from around 10 thousand in 2010 decreased to the thousand in 2014, and again increased to 6 thousand in 2015.

Table 2. Number of tourists and night in Kosovo

for the period 2010-2015 by statistical regions (Source: Kosovo Statistics Agency, 2016)

\begin{tabular}{|c|c|c|c|c|c|c|c|c|c|c|c|c|}
\hline \multirow[b]{2}{*}{$\begin{array}{l}\text { Statistical } \\
\text { region }\end{array}$} & \multicolumn{2}{|c|}{2010} & \multicolumn{2}{|c|}{2011} & \multicolumn{2}{|c|}{2012} & \multicolumn{2}{|c|}{2013} & \multicolumn{2}{|c|}{2014} & \multicolumn{2}{|c|}{2015} \\
\hline & $\begin{array}{l}\frac{n}{0} \\
0 \\
0 \\
0 \\
0 \\
0\end{array}$ & $\frac{\sum_{2}^{n}}{200}$ & 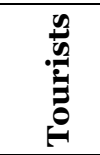 & 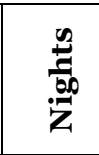 & 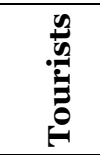 & 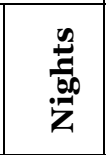 & 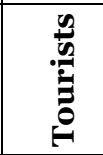 & 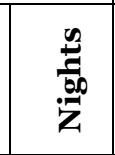 & $\begin{array}{l}0 \\
0 \\
0 \\
0 \\
0 \\
0\end{array}$ & $\begin{array}{l}\frac{y}{7} \\
\frac{1}{200} \\
z \\
Z\end{array}$ & 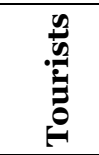 & 党 \\
\hline & 031 & & 640 & & & & & & 062 & & 2269 & \\
\hline & 1976 & & 2251 & & 1937 & & 1718 & -507 & 1552 & & 1635 & 149 \\
\hline ica & 2894 & 3289 & 2646 & 2890 & 2875 & 3088 & 2915 & 3147 & 2631 & 689 & 2247 & 2434 \\
\hline & 8337 & 9677 & 6633 & 7170 & 7593 & 1184 & 6630 & 9597 & 1534 & 18751 & 21707 & 33857 \\
\hline & 4663 & & 5434 & 46 & 212 & 962 & 8109 & 10360 & 8615 & 11144 & 16316 & 2130 \\
\hline Prishtina & 49172 & 83694 & 6636 & 80620 & 68537 & 102846 & 68687 & 102323 & 77167 & 114489 & 89050 & 13026 \\
\hline Ferizaj & 9972 & 10923 & 7153 & 7584 & 10012 & 12731 & 5878 & 8887 & 4229 & 4450 & 6214 & 6719 \\
\hline$\pi$ & 79045 & 121517 & 72393 & 10341 & 98763 & 14297 & 95454 & 138750 & 1077 & 1573 & & 2020 \\
\hline
\end{tabular}

\section{CONCLUSION}

- The central and local level policymaking sector has done little to develop sustainable tourism, has been more focused on economic development strategies, are involved in economic development strategies, and 1 institution is by developing tourism development strategies.

- None of the public tourism development agencies have regulatory plans for tourist areas; 4 institutions have allocated budget for tourism, while 6 do not share the financial budget for tourism development.

- For marketing strategy for tourism development 5 institutions think that this strategy serves the promotion of tourist potentials, the development of cross-border tourism. 3 institutions have stated that they have projects for the development of this type of tourism, while 7 have no projects for the development of international tourism.

- The private sector due to inadequate support from the public sector and its lack of involvement in drafting strategic documents, despite the investments made, is not highly oriented to tourism development sustainability.

- Regarding accommodation capacities, based on the tourism resources of the region, it is still to be desired. The importance of marketing for the development of tourist 
businesses has not yet been properly understood, many tourist businesses do not use the online booking system. Always informing the local community of important tourism projects should be timely and objective information of the competent institutions.

- The local community should be an integral part of important decision-making processes for sustainable tourism development.

- The local community through cooperation with the public and private sector should contribute to the development of sustainable tourism.

\section{REFERENCES}

Bajrami, H. (2015). Tourism in Kosovo and Sustainable Development.Thesis dissertation for Ph.D.s, Tirana p. 7.

Bakiu, V. (2011). Tourism and the determinates of its development. Tourism Economy. "Eric" Tirane Press, p. 12-19.

Bramwell B., \& Lane, B (2012). Towards Innovation in Sustainable Tourism Research? International Journal of Tourism Research, Volume 20, Issue 1, p.1-7.

Gashi, M. (1986). Basics of Tourism in Prishtina. Press "Rilindja".

Gunn, C.A. (1994). Tourisim planning. (3rd Ed) London: Taylor and Francis.

Maxwell J. (2005). Qualitative Research Design: An Interactive Approach”Applied Social Research Methods Series” Sage Publications (2 ${ }^{\text {nd }}$ Ed.).

Porritt, J. (2004). Making the Net Work: Sustainable Development in a Digital Society (https: //www. amazon.com/Making-Net-Work-Sustainable-Development/dp/o954621603 Pristina-flights sherrelirell.1).

Timur, S., \& Getz, D. (2008). A network perspective on managing stakeholders for sustainable urban tourism. International Journal of Contemporary Hospitality Management, v. 20, n. 4.”, p 445-461.

Weaver, D. (2006), Sustainable Tourism, Theory and Practice England, Elsevier Butterworth Heinemann.

*** Kosovo Statistics Agency, (2016). http://ask.rks-gov.net/.

*** WCED. (1987). Our common future. Oxford University Press p. 6.

*** WTO. (1993). Sustainable Tourism Development. Guide for local planners, ISBN: 978-92-844-0280-9.

http://www.ammk-rks.net dt. accessed 10.05.2018.

http://www.ammk-rks.net/?page=1,2 Rruga Luan Haradinaj, Ndërtesa e Re e Qeverisë së Kosovës (ish Pallati i Mediave Rlindja), Kati XV/o4, $1000 o$ Prishtinë, Republika e Kosovës 2018.

Submitted:

20.12.2017
Revised:

25.06.2018
Accepted and published online 27.06.2018 